\title{
« Eschatology - III. In imami shi'ism », EI, VIII, 6, edited by Ehsan Yarshater, Costa Mesa, CA, Mazda Publishers, 1998, pp. 575-581.
}

\section{Christian Jambet}

\section{(2) OpenEdition}

1 Journals

\section{Édition électronique}

URL : http://journals.openedition.org/abstractairanica/36721

DOI : 10.4000/abstractairanica.36721

ISSN : 1961-960X

Éditeur :

CNRS (UMR 7528 Mondes iraniens et indiens), Éditions de l'IFRI

\section{Édition imprimée}

Date de publication : 15 mai 2001

ISSN : 0240-8910

Référence électronique

Christian Jambet, « « Eschatology - III. In imami shi'ism », EI, VIII, 6, edited by Ehsan Yarshater, Costa Mesa, CA, Mazda Publishers, 1998, pp. 575-581. », Abstracta Iranica [En ligne], Volume 22 | 2001, document 314, mis en ligne le 17 février 2010, consulté le 10 octobre 2020. URL : http:// journals.openedition.org/abstractairanica/36721; DOI : https://doi.org/10.4000/abstractairanica 36721

Ce document a été généré automatiquement le 10 octobre 2020.

Tous droits réservés 


\title{
« Eschatology - III. In imami
} shi'ism », EI, VIII, 6, edited by Ehsan Yarshater, Costa Mesa, CA, Mazda Publishers, 1998, pp. 575-581.

\author{
Christian Jambet
}

Présentation très détaillée et documentée de la question des fins dernières selon la tradition originelle du shi'isme. Synthèse des données concernant le $Q \bar{a} ' e m$ et la résurrection, ainsi que l'illumination et la vision des fidèles. Bibliographie fondamentale exhaustive. L'A. souligne l'importance de l'héritage des anciennes religions de l'Iran et des sectes "hétérodoxes» judéo-chrétiennes. L'eschatologie imâmite est essentiellement gnostique et intègre l'idée d'un combat entre la suprême Intelligence, identifiée à l'imâm et les armées de l'Ignorance.

\section{INDEX}

Thèmes : 7. Islam

\section{AUTEURS}

CHRISTIAN JAMBET

Paris 